\title{
EKSPLORASI GEN ENZIM LIPASE PADA TANAH PENGOLAHAN LIMBAH KELAPA SAWIT DENGAN PENDEKATAN METAGENOMIK
}

\author{
Sri Sumarsih*, Andre Pratama, Afaf Baktir \\ Departemen Kimia, Fakultas Sains dan Teknologi, \\ Universitas Airlangga, Surabaya \\ *email: sri-sumarsih@fst.unait.ac.id,srimarish@yahoo.com
}

Received 20 Pebuari 2017

Accepted 20 April 2017

\begin{abstract}
Abstrak
Enzim lipase merupakan bagian dari enzim hidrolase yang bekerja pada ikatan ester. Enzim ini juga mengkatalisis beberapa jenis reaksi sehingga merupakan enzim yang potensial diaplikasikan ke berbagai bidang seperti industri tekstil, kulit, deterjen, makanan, dan lainlain. Salah satu cara mendapatkan enzim novel ialah dengan pendekatan secara metagenomik dari sampel lingkungan tanpa melalui kultur di dalam laboratorium. Sampel lingkungan yang biasa diteliti ialah memiliki keadaan ekstrem atau memiliki sumber substrat enzim yang ingin dieksplorasi. Pada penelitian ini dilakukan eksplorasi gen enzim lipase pada tanah hasil pengolahan limbah kelapa sawit (POME) melalui pendekatan metagenomik menggunakan desain primer degenerate untuk gen enzim lipase untuk golongan HSL. Didapatkan fragmen gen lipase yang memiliki ukuran 250-300 pasang basa dan dilakukan kloning ke dalam plasmid pET-30a(+) dengan sel inang E. coli TOP10 menghasilkan pustaka fragmen lipase limbah sawit (PFL2S) sebanyak 26 klon.
\end{abstract}

Kata kunci: Lipase, metagenomik, tanah, POME, primer degenerate

\begin{abstract}
Lipase is a hydrolase enzymes that cleavage on the ester bond. This enzyme is catalyze several reactions so this is a potential enzyme that applied to various fields such as textile, leather, detergents, food, and others. One of the method to get a novel enzyme is metagenomic approach from environmental samples without culturing in the laboratory. Environmental sample commonly studied is have an extreme environment or have a source of the enzyme substrate that researcher want explored. In this research, exploration lipase gene on the soil the processing of palm oil mill effluent (POME) through metagenomic approach using design of degenerate primers for lipase gene fragment for HSL group. Obtained lipase gene fragment size of 250-300 base pairs and cloned into pET-30a $(+)$ plasmid with the E. coli TOP10 as a host cells to produce libraries of lipase fragment gene of palm oil mill effluent (PFL2S) that have a 26 clones.
\end{abstract}

Keywords: Lipase, metagenomic, soil, POME, primer degenerate

\section{Pendahuluan}

Industri besar dan industri rumahan yang menggunakan katalis sekarang ini sangat bergantung dengan yang namanya enzim. Karena enzim dapat melakukan konversi dalam hitungan menit maupun detik (Otten and Quax, 2005). Selain itu, enzim juga dapat mengkatalis reaksi yang 
sulit dilakukan metode kimiawi seperti hidrolisis atau adisi enansioselektif maupun ragioselektif senyawa kiral. Kondisi reaksi dari enzim pun secara umum bisa dalam temperatur ruang dan ada enzim yang tahan pada suhu yang ekstrem serta kebanyakan bereaksi dalam pelarut air sehingga penelitian dan permintaan biokatalis terus berkembang pesat (Schoemaker, 2003).

Enzim lipase merupakan bagian dari enzim hidrolase yang bekerja pada ikatan ester. Lipase dapat menghidrolisis trigliserida menjadi digliserida, monogliserida, asam lemak, dan gliserol. Selain menghidrolisis ikatan ester, lipase juga dapat mengkatalisis reaksi esterifikasi, interesterifikasi, dan transesterifikasi pada media tanpa air (Momsia and Momsia, 2013). Kegunaan enzim lipase ini membuatnya menjadi enzim yang potensial untuk diaplikasikan ke berbagai bidang. Sehingga, sangat menarik untuk menemukan dan memproduksi enzim lipase dengan aktivitas tertentu karena banyak sekali potensi dari enzim lipase untuk diaplikasikan pada berbagai bidang.

Pendekatan secara metagenomik merupakan aplikasi dari genomik molekular untuk konsorsium mikroba yang tidak dapat dikultur dan dapat dipergunakan untuk mencari enzim industri yang baru karena keragaman materi genetik yang dianalisis (JunGang et al., 2010; Kakirde et al., 2010; Lämmle et al., 2007; Lorenz and Eck, 2005; Steele et al., 2009). Lebih dari $99 \%$ mikroorganisme tidak dapat dikultur (Handelsman et al., 1998), akibat kondisi pertumbuhannya yang belum diketahui atau pertumbuhannya memerlukan konsorsium mikroba. Berbagai macam lipase telah diisolasi melalui pendekatan metagenomik selama beberapa dekade (Glogauer et al., 2011; JunGang et al., 2010; Kakirde et al., 2010; Lämmle et al., 2007; Liaw et al., 2010; Lorenz and Eck, 2005; Simon and Daniel, 2009; Uchiyama and Miyazaki, 2009). Salah satu sampel lingkungan yang menarik untuk dianalisis enzim lipase dengan pendekatan metagenomik ialah sampel tanah dari limbah pengolahan kelapa sawit atau biasa disebut POME (Palm Oil Mill Effluent).

Pada penelitian ini dilakukan eksplorasi gen enzim lipase pada tanah hasil pengolahan limbah kelapa sawit (POME) melalui pendekatan metagenomik. Sampel diambil dari tanah milik PT. Agro Bukit Central Kalimantan, Sampit, Kalimantan Tengah, yang merupakan tempat proses biologis dari limbah pengolahan kelapa sawit yang salah satunya mengandung minyak. Metode yang digunakan ialah metode ekstraksi DNA berbasis SDS (Hurt et al., 2001) termodifikasi, DNA metagenom diekstraksi secara langsung dari sampel tanah dengan pengayaan mikroba terlebih dahulu dalam media Luria Bertani. Konstruksi pustaka metagenom dilakukan dengan cara kloning gen hasil PCR menggunakan vektor plasmid pET-30a(+) dan sel inang E. coli TOP10. Koleksi klon merupakan pustaka fragmen gen lipase dari sumber tanah limbah pengolahan kelapa sawit.

\section{Metode Penelitian Alat dan Bahan}

Alat utama yang digunakan antara lain: autoklaf, laminar air flow, shaker incubator, sentrifuga, nano drop spectrophotometer, Thermocycler, perangkat elektroforesis DNA, Gel Doc, pipet mikro berbagai ukuran, serta alat-alat gelas yang lazim digunakan di laboratorium mikrobiologi dan biokimia.

Bahan penelitian yang digunakan meliputi: Escherichia coli TOP10, pET30a(+),2-merkaptoetanol, Tris- $\mathrm{HCl}, \mathrm{NaCl}$, cetyltrimethylammonium bromide [CTAB], $\mathrm{NaH}_{2} \mathrm{PO}_{4}, \mathrm{Na}_{2} \mathrm{HPO}_{4}$, EDTA, sodium dodecyl sulphate (SDS), nitrogen cair, isopropanol, polietilen glikol (PEG 6000), kloroform, isoamil alcohol, GenElute $^{\text {tm }}$ Bacterial Genomic DNA Kit (Sigma Aldrich). KAPA2G Fast ReadyMix with Dye (Boston, Massachusetts, United States). QIAquick PCR purification kit 
(Qiagen), tripton, yeast extract, bacto agar, dan minyak zaitun, gel loading buffer, marker DNA, agarosa, etidium bromida (EtBr), asam asetat glasial, glukosa, $\mathrm{NaOH}, \mathrm{CaCl}_{2}$, natrium asetat, etanol $70 \%$, $\mathrm{dH}_{2} \mathrm{O}$, dan $\mathrm{ddH}_{2} \mathrm{O}$.

\section{Prosedur Peneltian}

Pengambilan sampel dan ekstraksi DNA

Sampel tanah dari Palm Oil Mill Effluent diambil dari pabrik pengolahan kelapa sawit milik PT. Agro Bukit Central Kalimantan yang terletak di jalan Sudirman Km 106 Sampit, Kalimantan Tengah $\quad\left(2^{\circ} 33^{\prime} 55.3^{\prime \prime} \mathrm{S}, \quad 112^{\circ} 46^{\prime} 03.5^{\prime \prime} \mathrm{E}\right)$ pada bulan Januari 2016. Ekstraksi DNA metagenom dilakukan dengan metode Hurt et al. (2001) termodifikasi. sampel tanah sebanyak 5 gr juga dilakukan pengayaan terlebih dahulu menggunakan $100 \mathrm{ml}$ media LB (Luria Bertani) cair dengan minyak zaitun $1 \%$ dan shaker selama semalam. Sampel dan hasil pengayaan ditambahkan $9 \mathrm{ml}$ buffer ekstraksi (100 mM natrium fosfat [pH 7,0], $100 \mathrm{mM}$ Tris-HCL [pH 7,0], $100 \mathrm{mM}$ EDTA [pH 8,0], 1,5 M NaCl, 1\% CTAB dan $2 \%$ SDS) dan diinkubasi selama 30 menit pada $65^{\circ} \mathrm{C}$ sambil diaduk tiap 10 menit lalu disentrifugasi pada $1800 \mathrm{x} \mathrm{g}$ selama 10 menit. Supernatan ekstraksi langsung sampel tanah dituangkan ke dalam tabung berpenangas es yang mengandung $20 \mathrm{ml}$ aliquot dari 25:24:1 fenol-kloroform-isoamil alkohol. Sedangkan supernatan ekstraksi dari hasil pengayaan dimurnikan dengan GenElute $e^{\text {tm }}$ Bacterial Genomic DNA Kit.

\section{Desain primer fragmen gen lipase}

Untuk mendapatkan gen target pada proses amplifikasi gen dengan PCR, dibutuhkan sepasang primer yang spesifik yaitu dengan cara dilakukan desain primer forward dan primer reverse (Shi et al., 2009). Primer degenerate yang di desain untuk amplifikasi fragmen gen lipase berdasarkan lipase golongan HSL yang telah dipublikasikan pada NCBI (http://www.ncbi.nlm.nih.gov/Entrez/).
Daerah lestari asam amino yang potensial diidentifikasi menggunakan Clustal W. Kemudian di awal basa dari primer yang didesain, ditambahkan beberapa basa pijakan dan urutan basa dari enzim restriksi SacI untuk forward dan HindIII untuk reverse.

\section{Konstruksi pustaka fragmen gen lipase}

Proses amplifikasi gen fragmen lipase menggunakan teknik PCR dan kit KAPA2G Fast ReadyMix with Dye dengan primer CLF dan CLR. PCR dilakukan sebanyak 35 siklus sebagai berikut: predenaturasi pada suhu $95^{\circ} \mathrm{C}$ selama 3 menit, denaturasi suhu $95^{\circ} \mathrm{C}$ selama 15 detik, annealing suhu $63,2^{\circ} \mathrm{C} ; 64,4^{\circ} \mathrm{C} ; 66,8^{\circ} \mathrm{C}$; $68 \mathrm{oC}$, dan $69,5^{\circ} \mathrm{C}$ selama 15 detik, elongasi suhu $72^{\circ} \mathrm{C}$ selama 15 detik dan pasca-elongasi suhu $72^{\circ} \mathrm{C}$ selama 1 menit. hasil PCR dimurnikan menggunakan QIAquick PCR purification kit (Qiagen). Untuk konstruksi pustaka fragmen gen lipase, hasil purifikasi PCR dilakukan kloning gen dengan vektor pET-30a(+) dan transformasi ke dalam E. coli TOP10 melalui heat shock.

\section{Hasil dan Pembahasan}

Sampel tanah diambil sedalam $3 \mathrm{~cm}$ dari permukaan tanah dan berasal dari 2 titik yaitu dasar kolam dan pinggir kolam. Pengambilan pada 2 titik ini bertujuan agar mikroorganisme yang didapatkan merupakan mikroorganisme aerob dan anaerob. Karakteristik tanah secara fisik berupa tanah liat berwarna hitam (dasar kolam) dan coklat (pinggir kolam).

Hasil panen pelet dilakukan ekstraksi menggunakan buffer ekstraksi DNA tanpa melalui ekstraksi DNA secara fisik serta dilakukan perbandingan hasil dengan menggunakan kit. Supernatant diambil dan dilakukan pemurnian DNA metagenom menggunakan kolom GenElute ${ }^{t m}$ Bacterial Genomic DNA Kit (Sigma Aldrich). Didapatkan DNA metagenome dari kedua media kultur pada kondisi yang berbeda. Dapat dilihat dari hasil elektroforesis 
berupa elektroforegram dengan band DNA berkisar $20 \mathrm{~kb}$ (Gambar 1).

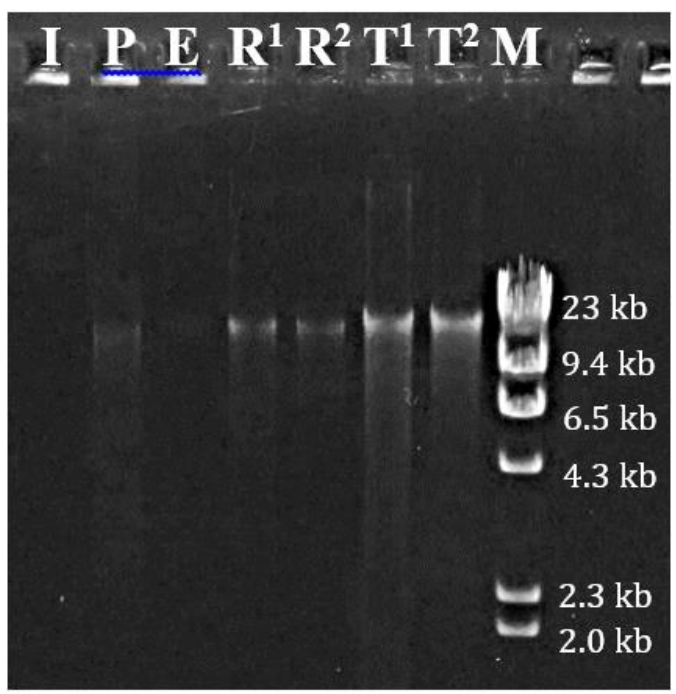

Gambar 1. Elektroforegram DNA metagenom dari sampel tanah.

(I) dengan isopropyl alkohol, (P) dengan PEG 6000, (E) dengan etanol, $\left(\mathrm{R}^{1}, \mathrm{R}^{2}\right)$ suhu ruang, $\left(\mathrm{T}^{1}, \mathrm{~T}^{2}\right)$ suhu tinggi, $(\mathrm{M})$ Marker DNA $\lambda /$ HindIII.

Tingkat kemurnian sampel DNA metagenom dari kedua media kultur bisa dikatakan murni karena memenuhi rentang kemurnian DNA yang baik (Tabel 1). sehingga dapat digunakan pada tahap selanjutnya. Konsentrasi DNA pada media bersuhu tinggi lebih besar dibandingkan media pada suhu ruang. Hal ini bisa disebabkan karena lingkungan asli tanah pada kolam limbah ialah bersuhu tinggi (Rupani and Singh, 2010;
Soleimaninanadegani and Manshad, 2014) sehingga lebih banyak mikroorganisme berkembang pada suhu tinggi $\left(60^{\circ} \mathrm{C}\right)$.

Untuk mendapatkan gen penyandi lipase, digunakan primer degenerate yang berasal dari lipase golongan HSL atau hormone sensitive lipase (Shi et al., 2009). Primer degenerate didesain berdasarkan gen lipase golongan HSL dengan pencarian Entrez pada NCBI (http://www.ncbi.nlm.nih.gov/Entrez/).

Dua daerah lestari pada H-G dan G-X$\mathrm{S}-\mathrm{X}-\mathrm{G}$ (X merupakan asam amino) ditemukan pada kebanyakan lipase yaitu daerah lestari untuk lubang oksianion dan sisi aktif enzim (Jaeger et al., 1994; Kim et al., 2004). Pada lipase golongan HSL berdasarkan 6 mikroorganisme yang disejajarkan urutan asam aminonya. Didapat 2 daerah lestari pada lubang oksianion yaitu [V/L]-[F/Y/D]-[F/I]-H-GG-[G/A] dan sisi aktif enzim HSL lipase yaitu G̈-[D/V]-S-[A/V]-G-G-[N/C]$[\mathrm{L} / \mathrm{M} / \mathrm{I}]$. Setelah itu, didesain primer yang komplemen dengan dua daerah lestari tersebut. Untuk mengecek primer yang didesain, dilakukan tes pada susunan gen lipase yang diketahui dan membandingkan hasil primer dengan susunan gen lipase yang telah terpublikasi menggunakan BLASTx (http://www.ncbi. nlm.nih.gov/blast/Blast.cgi). Setelah beberapa kali dioptimasi, didapatkan primer degenerate CLF (Cold Lipase Forward) dan CLR (Cold Lipase Reverse) (Tabel 2).

Tabel 1. hasil spektrofotometri nanodrop

\begin{tabular}{ccccccc}
\hline Sample & $\mathbf{2 3 0}$ & $\mathbf{2 6 0}$ & $\mathbf{2 8 0}$ & $\mathbf{2 6 0 / 2 8 0}$ & $\mathbf{2 6 0 / 2 3 0}$ & $\mathbf{n g} / \boldsymbol{\mu l}$ \\
\hline $\mathrm{T}^{1}$ & 6,854 & 5,264 & 3,413 & 1,54 & 0,77 & 263,2 \\
$\mathrm{~T}^{2}$ & 4,489 & 6,342 & 3,312 & 1,91 & 1,41 & 317,1 \\
$\mathrm{R}^{1}$ & 0,977 & 0,674 & 0,387 & 1,74 & 0,69 & 33,7 \\
$\mathrm{R}^{2}$ & 0,67 & 0,669 & 0,347 & 1,93 & 1 & 33,4 \\
Manual PEG 6000 & 32,77 & 60,508 & 44,126 & 1,37 & 1,85 & 3025,4 \\
\hline
\end{tabular}


Proses amplifikasi gen penyandi fragmen lipase dilakukan dengan memvariasi suhu penempelan primer atau annealing yaitu pada suhu $63,2^{\circ} \mathrm{C} ; 64,4^{\circ} \mathrm{C}$; $66,8^{\circ} \mathrm{C} ; 68^{\circ} \mathrm{C}$, dan $69,5^{\circ} \mathrm{C}$. Variasi suhu dilakukan dengan tujuan untuk menentukan suhu optimal dari primer agar dapat menempel pada DNA template secara sempurna sehingga didapatkan fragmen DNA dari gen penyandi lipase. Dari hasil variasi tersebut, fragmen gen lipase dapat teramplifikasi dengan suhu annealing $63,2^{\circ} \mathrm{C}$ dan $64,4^{\circ} \mathrm{C}$ (Gambar 3). Amplikon yang di dapatkan dari hasil PCR dengan menggunakan primer CLF dan CLR memiliki ukuran basa sebesar 250300 pasang basa. Hal ini sesuai pada penelitian yang telah dilakukan oleh Shi et al. (2009) dan Yan et al. (2016). Dari 4 sampel DNA metagenom, hanya sampel dari pengayaan pada suhu ruang yang positif menghasilkan amplikon fragmen gen lipase golongan HSL. Hal ini menunjukkan bahwa tidak ada mikroorganisme penghasil lipase golongan HSL pada suhu tinggi karena mikroorganisme golongan HSL ini hidup pada suhu rendah (Shi et al., 2009). Hasil PCR kemudian dipurifikasi menggunakan kolom QIAquick PCR purification kit (Qiagen). Lalu dilakukan kloning gen dan

\section{Daftar Pustaka}

Glogauer, A., Martini, V.P., Faoro, H., Couto, G.H., Müller-santos, M., Monteiro, R.A., Mitchell, D.A., Souza, E.M. De, Pedrosa, F.O., Krieger, N., 2011. Identification and characterization of a new true lipase isolated through metagenomic approach. Microb. Cell Fact. 10, 54.

Handelsman, J., Rondon, M.R., Brady, S.F., Clardy, J., Goodman, R.M., 1998. Molecular biological access to the chemistry of unknown soil microbes: a new frontier for natural products. Chem. Biol. 5, R245-R249. menghasilkan klon yang tumbuh sebanyak 26 klon
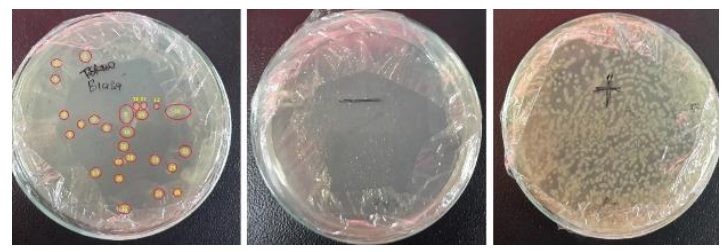

Gambar 4. Hasil transformasi. (kiri) klon plasmid rekombinan fragmen gen lipase, (tengah) kontrol negatif, (kanan) kontrol positif.

\section{Kesimpulan}

Tingkat kemurnian hasil ekstraksi DNA sampel tanah pengolahan limbah kelapa sawit menggunakan metode Hurt et al. (2001) termodifikasi mempunyai rasio absorbansi 260/280 sebesar 1,93 serta ukurannya berkisar 20 bp. Primer degenerate CLF dan CLR dapat mengamplifikasi fragmen gen lipase dari sampel tanah pengolahan limbah kelapa sawit dengan ukuran 250-300 bp. Hasil transformasi plasmid pET-30a(+) tersisipi fragmen gen lipase menghasilkan pustaka klon sebanyak 26 klon yang disebut pustaka fragmen lipase limbah sawit (PFL2S).

Hurt, R.A., Qiu, X., Wu, L., Roh, Y., Tiedje, J.M., Zhou, J., Hurt, R.A., Qiu, X., Wu, L., Roh, Y.U.L., Palumbo, A. V, 2001. Simultaneous Recovery of RNA and DNA from Soils and Sediments. Appl. Environ. Microbiol. 67.

Jun Gang, L., Ke Gui, Z., Wen Jun, H., 2010. Cloning and biochemical characterization of a novel lipolytic gene from activated sludge metagenome, and its gene product. Microb. Cell Fact. 9, 83. 
Kakirde, K.S., Parsley, L.C., Liles, M.R., 2010. Size does matter: Applicationdriven approaches for soil metagenomics. Soil Biol. Biochem. 42, 1911-1923.

Lämmle, K., Zipper, H., Breuer, M., Hauer, B., Buta, C., Brunner, H., Rupp, S., 2007. Identification of novel enzymes with different hydrolytic activities by metagenome expression cloning. J. Biotechnol. 127, 575-592.

Liaw, R. B., Cheng, M. P., Wu, M. C., Lee, C. Y., 2010. Use of metagenomic approaches to isolate lipolytic genes from activated sludge. Bioresour. Technol. 101, 8323-9.

Lorenz, P., Eck, J., 2005. Metagenomics and industrial applications. Nature 3, 510-516.

Momsia, T., Momsia, P., 2013. A review on " microbial lipase-versatile tool for industrial applications ." Int. J. life Sci. Biotechnol. pharma Res. 2.

Otten, L.G., Quax, W.J., 2005. Directed evolution: selecting today's biocatalysts. Biomol. Eng. 22, 1-9.

Schoemaker, H.E., 2003. Dispelling the Myths--Biocatalysis in Industrial Synthesis. Science 299, 1694-1697.
Shi, P., Liu, W., Meng, K., Bai, Y., Wang, G., Zhan, Z., Yao, B., 2009. Lipase Diversity in Glacier Soil Based on Analysis of Metagenomic DNA Fragments and Cell Culture 19, 888897.

Simon, C., Daniel, R., 2009. Achievements and new knowledge unraveled by metagenomic approaches. Appl. Microbiol. Biotechnol. 85, 265-276.

Steele, H. L., Jaeger, K. E., Daniel, R., Streit, W. R., 2009. Advances in Recovery of Novel Biocatalysts from Metagenomes. J. Mol. Microbiol. Biotechnol. 16, 25-37.

Uchiyama, T., Miyazaki, K., 2009. Functional metagenomics for enzyme discovery: challenges to efficient screening. Curr. Opin. Biotechnol. 20, 616-622.

Yan, Q., Duan, X., Liu, Y., Jiang, Z., Yang, S., 2016. Biotechnology for Biofuels Expression and characterization of a novel 1,3 regioselective cold - adapted lipase from Rhizomucor endophyticus suitable for biodiesel synthesis. Biotechnol. Biofuels 1-13 